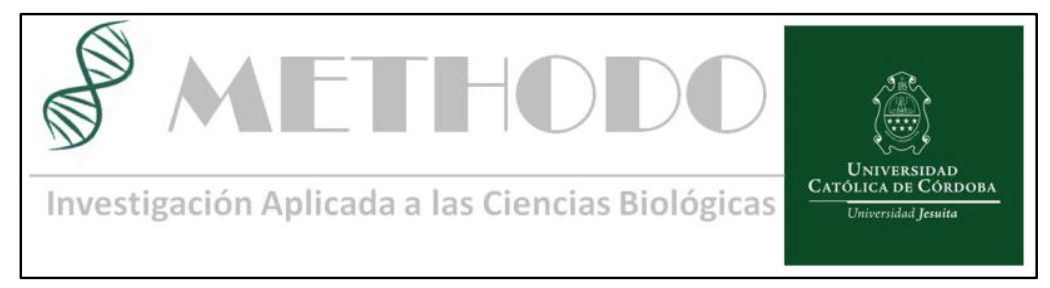

\title{
Caracterización de la población estudiada para mutaciones BRCA 1 Y 2 dentro de un programa de asesoramiento familiar
}

\section{Characterization of the population studied for BRCA 1 and 2 mutations within a family counseling program.}

\author{
Melina Winocur ${ }^{1}$, José Llugdar ${ }^{1}$, Matías Cortes ${ }^{1}$, Cristina Baiud ${ }^{1}$, Santiago Bella ${ }^{1}$. \\ 1Servicio de Oncología. Clínica Universitaria Reina Fabiola, Universidad Católica de Córdoba. Correspondencia: Melina Winocur Servicio de Oncología. Clínica \\ Universitaria Reina Fabiola. Oncativo 1248-X5004FHP-Córdoba, Argentina; e-mail: melinawinocur@gmail.com
}

\section{Introducción}

Alrededor del 10 al $20 \%$ de las mujeres con cáncer de mama tienen uno o más familiares de primer grado que también están afectados por cáncer de mama $^{1,2}$. Aunque sólo del 5 al $10 \%$ de las mujeres no seleccionadas con cáncer de mama tienen una forma hereditaria, asociado a un gen mutado, deficitario en su función, hasta el $20 \%$ de las mujeres con antecedentes familiares de cáncer de mama tienen una mutación en un gen de predisposición a cáncer de moderada o alta penetrancia ${ }^{3}$.

Objetivo primario

Describir los antecedentes oncológicos personales y familiares de pacientes a los que se les solicitó el estudio de mutaciones BRCA 1 y BRCA 2 y compararlos con los criterios usados en guías nacionales (INC) e internacionales (NCCN)compararlos con los criterios usados en guías nacionales (INC) e internacionales (NCCN)

\section{Materiales y métodos}

Diseño: Estudio retrospectivo, descriptivo y observacional.

Población: Se analizarán todas las historias clínicas de los pacientes a los cuales se les haya realizado el proceso de asesoramiento enético y solicitado el estudio para mutaciones BRCA 1 y 2 desde: julio 15 hasta julio 2018, en la Clínica Universitaria Reina Fabiola e instituto Oulton.

\section{Resultados}

Se solicitó el estudio para mutaciones deletéreas de genes BRCA 1 y 2 a 94 individuos. La edad promedio fue de 45 años. De los 94 individuos 61 tenían cáncer de mama $\quad(64,89 \%), 10$ cáncer de ovario (10,63\%), y 23 (24\%) no tenían cancer.Del total de individuos, 30 no se lo realizaron por diferentes motivos: $13(43 \%)$ por motivos personales, $3(10 \%)$ por falta de cobertura de la obra social, $14(46 \%)$ no retornaron a consulta.Todos, excepto dos pacientes a quienes se le solicitó el estudio de mutaciones BRCA 1 y 2 cumpían los criterios de las guías americanas y nacionales para el testeo de la mutación.

De los 64 individuos que realizaron el test, 14 $(21,87 \%)$ tenían mutaciones deletéreas, 1 de significado incierto, y 49 dieron negativos $(76,5 \%)$.

De las 61 pacientes con cáncer de mama estudiadas, 48 (78\%) eran menores de 50 años, 24 $(39,3 \%)$ tenían tumores triple negativos, 19 (31\%) ganglios axilares positivos, 13 (21\%) tumores luminales, 31 (50\%) antecedentes familiares de cáncer relacionado con las mutaciones BRCA 1 Y 2, 2 de ellas (3\%) eran de origen judío askenazi. Dentro los 14 pacientes con mutaciones BRCA, 10 (71\%) presentaban mutación BRCA 1 y 4 (28\%) en el gen BRCA 2. De los mismos, 8 (57\%) tenían cáncer de mama, 2 (14\%) cáncer de ovario, 4 (28\%) no tenían cáncer.

De las 8 pacientes con BRCA mutado con cáncer de mama: todas eran menor de 50 años. 3 tenían tumores triple negativos, ninguna tenía familiares 
con enfermedad oncológica relacionada, 3 tenían ganglios axilares positivos, 2 eran pacientes con tumores luminales.

1 era her2 positivo.

De los pacientes con mutaciones positivas con cáncer de ovario, ambas pacientes tenían más de 65 años, tumores serosos y ninguna tenía antecedentes familiares de cáncer.

\section{Conclusiones}

Podemos concluir que la población estudiada en nuestra serie, coincide con los factores de riesgo para screening de mutaciones BRCA según NCCN en cuanto a: edad menor de 50 años, factores de riesgo heredofamiliares, la variedad de los tumores de mama, el tipo histológico de los tumores de ovario.

\section{Introduction}

About 10 to $20 \%$ of women with breast cancer have one or more first degree relatives who are also affected by breast cancer ${ }^{1,2}$. Although only 5 to $10 \%$ of women not selected with breast cancer have a hereditary form, associated with a mutated gene, deficient in their function, up to $20 \%$ of women with a family history of breast cancer have a mutation in a predisposition gene for cancer of moderate or high penetrance ${ }^{3}$. Primary objective: To describe the personal and family oncological history of patients who were asked to study BRCA 1 and BRCA 2 mutations and compare them with the criteria used in national (INC) and international (NCCN) guidelines Design: Retrospective, descriptive and observational study. Population: All the clinical histories of the patients who have undergone the genetic counseling process and the study for BRCA 1 and 2 mutations from July 2015 to July 2018, at the Reina Fabiola University Clinic and Oulton, will be analyzed.

\section{Results}

The study was requested for deleterious mutations of BRCA 1 and 2 genes in 94 individuals.

The average age was 45 years. Of the 94 individuals, 61 had breast cancer $(64.89 \%), 10$ ovarian cancer (10.63\%), and 23 (24\%) had no cancer.

Of the total number of individuals, 30 were not carried out for different reasons: $13(43 \%)$ for personal reasons, $3(10 \%)$ for lack of social work coverage, $14(46 \%)$ did not return to consultation All but two patients who were asked to study BRCA 1 and 2 mutations met the criteria of the American and national guidelines for mutation testing.
Of the 64 individuals who performed the test, 14 $(21.87 \%)$ had deleterious mutations, 1 of uncertain significance, and 49 were negative $(76.5 \%)$.

Of the 61 patients with breast cancer studied, 48 (78\%) were younger than 50 years old, 24 (39.3\%) had triple negative tumors, $19(31 \%)$ positive axillary lymph nodes, 13 (21\%) luminal tumors, 31 $(50 \%)$ family history of cancer related to BRCA 1 and 2 mutations, 2 of them (3\%) were of Ashkenazi Jewish origin.

Within the 14 patients with BRCA mutations, 10 $(71 \%)$ had a BRCA 1 and $4(28 \%)$ mutation in the BRCA 2 gene. Of these, $8(57 \%)$ had breast cancer, $2(14 \%)$ cancer ovary, 4 (28\%) did not have cancer.

Of the 8 patients with BRCA mutated with breast cancer: all were younger than 50 years

3 had triple negative tumors, none had relatives with related oncological disease, 3 had positive axillary nodes, 2 were patients with luminal tumors 1 was her2 positive.

Of the patients with positive mutations with ovarian cancer, both patients were over 65 years old, had serous tumors and none had a family history of cancer.

\section{Conclusions}

We can conclude that the population studied in our series coincides with the risk factors for screening BRCA mutations according to NCCN in terms of: age under 50 years, heredity-familial risk factors, the variety of breast tumors, the histological type of Ovarian tumors.

\section{Bibliografía}

1. Grupo Colaborativo sobre Factores Hormonales en el Cáncer de Mama. Cáncer de mama familiar: reanálisis colaborativo de datos individuales de 52 estudios epidemiológicos que incluyeron a 58,209 mujeres con cáncer de mama y 101,986 mujeres sin la enfermedad. Lancet 2001; 358: 1389.

2. Slattery ML, Kerber RA. Una evaluación exhaustiva de los antecedentes familiares y el riesgo de cáncer de mama. La base de datos de población de Utah. JAMA 1993; 270: 1563.

3. Couch FJ, Nathanson KL, Offit K. Dos décadas después de BRCA: establecer paradigmas en la atención y prevención personalizada del cáncer. Science 2014; 343: 1466. 
Winocur M, Llugdar J, Cortes M, Baiud C, Bella S. Caracterización de la población estudiada para mutaciones BRCA 1 Y 2 dentro de un programa de asesoramiento familiar.

\section{Palabras claves}

BRCA 1 Y 2, FACTORES DE RIESGO,

CÁNCER DE MAMA, CÁNCER DE OVARIO

\section{Keywords}

BRCA 1 AND 2, RISK FACTORS, BREAST

CANCER, OVARIAN CANCER

$$
\text { (c) (i) (1) (O) }
$$

